\title{
Effects of water-borne copper on the survival, antioxidant status, metallothionein-I mRNA expression and physiological responses of the Chinese mitten crab, Eriocheir sinensis (Decapoda: Brachyura) larvae
}

\author{
Shengming Sun ${ }^{1,2}$, Xianping $\mathrm{Ge}^{1}$, Jian Zhu ${ }^{1}$, Hongtuo $\mathrm{Fu}^{1}$, Zhiqiang Jiang ${ }^{2}$ \\ ${ }^{1}$ Key Laboratory of Genetic Breeding and Aquaculture Biology of Freshwater Fishes, Ministry of Agriculture, Freshwater \\ Fisheries Research Center, Chinese Academy of Fishery Sciences, Wuxi 214081, PR China. E-mail: gexp@ffrc.cn \\ ${ }^{2}$ School of Life Science, Dalian Ocean University, Dalian 116023, PR China.
}

\begin{abstract}
Summary: The lethal concentration of water-borne copper in Chinese mitten crab Eriocheir sinensis larvae was tested by exposing the animals to $0,0.1,0.2,0.3,0.5$ and $0.8 \mathrm{mg} \mathrm{Cu} \mathrm{L}^{-1}$ at $20^{\circ} \mathrm{C}$ for $96 \mathrm{~h}$. The $96-\mathrm{h}$ median lethal concentration $\left(\mathrm{LC}_{50}\right)$ and its corresponding 95\% confident interval was estimated on zoea 1 larvae and megalopa larvae, respectively. Acute dissolved copper toxicity was higher for zoea 1 larvae $\left(0.16 \mathrm{mg} \mathrm{L}^{-1}\right)$ than for megalopa larvae $\left(0.21 \mathrm{mg} \mathrm{L}^{-1}\right)$. The antioxidant status, metallothionein-I mRNA expression and physiological response of the crab to copper toxicity was further investigated by exposing the megalopa larvae to $0,0.08$ and $0.16 \mathrm{mg} \mathrm{Cu} \mathrm{L}^{-1}$ for $96 \mathrm{~h}$. The superoxide dismutase activity, catalase activity, glutathione S-transferase (GST) activity and lipid peroxidation content of megalopa larvae increased concomitantly with the exposure time and copper concentration. MT-I mRNA expression levels were positively correlated with both the concentration and duration of copper exposure. The oxygen consumption and respiratory quotient of megalopa larvae in response to $0.16 \mathrm{mg} \mathrm{L}^{-1}$ copper were significantly higher than those in the control group after $96 \mathrm{~h}$ of exposure $(P<0.05)$. The results of this study highlight the potential effects of copper as a common stressor in E. sinensis larvae. MT-I and GST appear to be suitable biomarkers of environmental copper exposure stress in E. sinensis larvae.
\end{abstract}

Keywords: Eriocheir sinensis; copper toxicity; physiological; larvae; antioxidant enzyme; metallothionein.

Efectos del cobre disuelto sobre la supervivencia, estado antioxidante, expresión de la metalotionina-I mRNA y la respuesta fisiológica de las larvas del cangrejo de Shangai, Eriocheir sinensis (Decapoda: Brachyura)

Resumen: La concentración letal de cobre disuelto se determina mediante la exposición de larvas del cangrejo de Shangai (Eriocheir sinensis) a dosis de $0,0.1,0.2,0.3,0.5$ y $0.8 \mathrm{mg} \mathrm{Cu} \mathrm{L}^{-1}$, a $20^{\circ} \mathrm{C}$ durante $96 \mathrm{~h}$. La concentración letal media $\left(\mathrm{LC}_{50}\right)$ y su correspondiente intervalo de confianza del $95 \%$ fueron estimados en los estadios larvales zoea I y megalopa. La toxicidad aguda del cobre disuelto fue mayor sobre larvas de zoea I $\left(0.16 \mathrm{mg} \mathrm{L}^{-1}\right)$ que sobre las de megalopa $\left(0.21 \mathrm{mg} \mathrm{L}^{-1}\right)$. El estado antioxidante, la expresión del mRNA de la metalotionina-I y la respuesta fisiológica del cangrejo a la toxicidad del cobre fueron posteriormente investigados exponiendo las larvas de megalopa a dosis de $0,0.08$ y $0.16 \mathrm{mg} \mathrm{Cu} \mathrm{L}^{-1}$ durante $96 \mathrm{~h}$. La actividad de la superóxido dismutasa (SOD), de la catalasa (CAT), de la glutatión-S-transferasa (GST) y la peroxidación lipídica de las larvas de megalopa se incrementó en relación con el tiempo de exposición y la concentración de cobre. Los niveles de expresión de MT-1 mRNA se correlacionaron positivamente con la concentración de cobre y el tiempo de exposición. El consumo de oxígeno y la tasa respiratoria de las larvas de megalopa fueron significativamente más elevadas que las del grupo control $(\mathrm{P}<0.05)$ en respuesta a dosis de $0.16 \mathrm{mg} \mathrm{Cu} \mathrm{L}^{-1}$, durante $96 \mathrm{~h}$ de exposición. Los resultados presentados en este estudio ponen de manifiesto los efectos potenciales del cobre como factor de estrés sobre las larvas de $E$. sinensis. MT-I y GST parecen ser adecuados biomarcadores de estrés a la exposición de $\mathrm{Cu}$ ambiental en larvas de E. sinensis.

Palabras clave: Eriocheir sinensis; toxicidad del cobre; fisiológica; larvas; enzima antioxidante; metalotionina.

Citation/Como citar este artículo: Sun S., Ge X., Zhu J., Fu H., Jiang Z. 2014. Effects of water-borne copper on the survival, antioxidant status, metallothionein-I mRNA expression and physiological responses of the Chinese mitten crab, Eriocheir sinensis (Decapoda: Brachyura) larvae. Sci. Mar. 78(1): 91-97. doi: http://dx.doi.org/10.3989/scimar.03929.06B

Editor: C. Porte.

Received: July 26, 2013. Accepted: November 14, 2013. Published: February 24, 2014.

Copyright: () 2014 CSIC. This is an open-access article distributed under the Creative Commons Attribution-Non Commercial Lisence (by-nc) Spain 3.0. 


\section{INTRODUCTION}

Copper sulphate is an important biocide commonly used in aquaculture to reduce the abundance of phytoplankton, including Microcystis and other blue-green algae (Yang et al. 2007). Aquatic animals acquire an unpleasant flavour when kept in water containing blue-green algae (Yeh et al. 2004). Therefore, Chinese farmers often use copper sulphate to eradicate filamentous algae during pond management of the Chinese mitten crab (Eriocheir sinensis Milne-Edwards, 1853), which is one of the most commercially important crustaceans used in aquaculture. In addition, multiple human activities have considerably expanded the input of copper into estuaries and marine environments around the world (D'Adamo et al. 2008). For example, an increase in copper concentration was observed near the Yangtze River and the Liaohe River estuary in China (Lin et al. 2002, Hou et al. 2011), where megalopa larval stages of $E$. sinensis migrate to freshwater to grow. The average copper concentration in these areas can reach $0.07 \mathrm{mg} \mathrm{L}^{-1}$, which is seven times higher than levels stipulated by the Chinese National Water Quality Standard for Fisheries (GB 11607-89) (Li and Li 2003). Copper can be potentially toxic to aquatic organisms when the internally available concentration exceeds the capacity of the physiological and biochemical detoxification abilities of aquatic animals (Sunda and Hanson 1987, Rainbow 1992). This results in protective mechanisms (metallothioneins [MTs] and antioxidant enzymes) failing to protect against lipid peroxidation (LPO) of cell membranes. Numerous investigations have shown the inhibitory effects of copper overdoses on the metabolic processes of crustaceans (Zapata et al. 2001, Yang et al. 2006a, 2006b, Li et al. 2008, Amin and Comoglio 2010), including effects related to aerobic metabolism and oxidative stress. As the reactive oxygen species (ROS), such as the superoxide radicals $\left(\mathrm{O}_{2}^{-}\right)$, hydrogen peroxide $\left(\mathrm{H}_{2} \mathrm{O}_{2}\right)$ and hydroxyl radicals $\left(\mathrm{OH}^{-}\right)$, are also continuously being formed during normal aerobic metabolism and many oxidative stress processes, all organisms have generated antioxidant defences with both enzymatic and non-enzymatic components. Antioxidant enzymes represent the enzymatic defences that are mainly involved in this context: superoxide dismutase (SOD) and catalase (CAT) remove $\mathrm{O}_{2}{ }^{-}$and $\mathrm{H}_{2} \mathrm{O}_{2}$ directly, respectively, while glutathione S-transferase (GST) catalyses the conjugation of the reduced form of glutathione to xenobiotic substrates for the purpose of detoxification (Hotard and Zou, 2008).

The lethal effect of copper on different growth stages of crustaceans has been studied extensively, for example in adult blue crabs (Callinectes sapidus) (Martins Cde et al. 2011), larval southern king crabs (Lithodes santolla) (Amin and Comoglio 2010) and juvenile freshwater crabs (Barytelphusa cunicularis) (Chourpagar and Kulkarni 2011). However, no study has yet evaluated the acute toxicity of copper on Chinese mitten crabs (E. sinensis) zoea 1 and megalopa larvae. Their habitats are strictly confined to water bodies, and they are more commonly exposed to toxic compounds dissolved in estuaries (Agrahari 2009). Considering the fact that the same species could show a differential susceptibility to pollutants throughout its various life stages (Bambang et al. 1995), we used E. sinensis larvae as experimental models to test their physiological responses to acute toxicity of copper.

The MT protein family has multiple physiological functions and diverse regulatory activities, which include metal homeostasis, heavy-metal detoxification and antioxidant protection from free radicals (Coyle et al. 2002, Haq et al. 2003). Three MT isoform-encoding genes have been identified in crustaceans: MT-I, which is inducible by cadmium, zinc, and copper; MT-II, which is inducible by zinc and cadmium; and MT-III, which is inducible by copper only (Brouwer et al. 1992, 1995, Syring et al. 2000). For our study, we chose only the MT-I gene as no copper-induced MT-III is present in intermoult-stage crustaceans (Brouwer et al. 2002). MT has been suggested to be a biomarker for evaluating heavy-metal pollution (Leung and Furness 1999, Correia et al. 2002, De Boeck et al. 2003). However, no attempt has yet been made to study MT gene expression levels in $E$. sinensis larvae.

In this study, we focused on the toxic effects of copper sulphate pollution on the antioxidant enzyme activity and respiration metabolism of E. sinensis larvae. We also aimed to assess the sensitivity of MT mRNA expression levels and the extent of LPO as effective environmental indicators for copper exposure in $E$. sinensis larvae.

\section{MATERIALS AND METHODS}

\section{Animals and rearing conditions}

Zoea 1 larvae and megalopa larvae of E. sinensis were obtained from the Guanghe Co. Fishery Co. Ltd., China. They were immediately transferred to an aquatic laboratory and held in a plastic tank $(100 \times 80 \times 50$ $\mathrm{cm})$. During acclimation and toxicity bioassays, the physico-chemical water parameters of the pre-aerated filtered seawater (size mesh, $0.22 \mu \mathrm{m}$ ) in the tank were as follows: temperature, $20 \pm 1^{\circ} \mathrm{C}$; $\mathrm{pH}, 8.35 \pm 0.08$; salinity, 20-21; dissolved oxygen, 5.16-6.53 $\mathrm{mg} \mathrm{L}^{-1}$; and total ammonia-nitrogen, below $0.08-0.09 \mathrm{mg} \mathrm{L}^{-1}$. The water exchange rate was $50 \%$ per day, and the photoperiod was maintained at $14 \mathrm{~L}: 10 \mathrm{D}$ with white fluorescent tubes.

\section{Acute lethal concentration of copper}

The copper solution was prepared with $\mathrm{CuSO}_{4} \cdot 5 \mathrm{H}_{2} \mathrm{O}$ (Analytical Reagent, Shanghai Chemical Co., Shanghai, China). After several pre-trials, six levels of copper sulphate $\left(0,0.1,0.2,0.3,0.5\right.$ and $\left.0.8 \mathrm{mg} \mathrm{Cu} \mathrm{L}^{-1}\right)$ were used to estimate the median lethal concentration $\left(\mathrm{LC}_{50}\right)$ of zoea 1 larvae and megalopa larvae, respectively. All test solutions were refreshed daily. Only actively swimming larvae were selected for the assays, and no feed was supplied to the larval crabs during the test period. In total, 9000 zoea 1 larvae and 360 mega- 
lopa larvae were randomly selected for the 96-h acute toxicity test. At each copper level, 150 zoea 1 larvae were stocked in triplicate $800-\mathrm{ml}$ beakers containing $500 \mathrm{~mL}$ filtered seawater, and 60 megalopa larvae were stocked in triplicate $2000-\mathrm{mL}$ beakers containing 1500 $\mathrm{ml}$ filtered seawater. Observations on mortality and abnormal behaviour of the larval crabs were conducted at least twice each day. During the test, water quality conditions were the same as during the acclimatization period. At 24, 48, 72 and $96 \mathrm{~h}$, we separately counted the number of crabs killed and the number of crabs exposed to each copper concentration. Larvae were considered dead when there was no movement of the appendages and when they did not respond to prodding with a glass pipette. The 96-h $\mathrm{LC}_{50}$ and its $95 \%$ confidence limits were estimated using a Probit analysis (Finney 1971). Measured concentrations of copper in the test solutions were accordant with calculated concentrations.

\section{Water-borne copper exposure}

Based on the $\mathrm{LC}_{50}$ estimate, 12 rectangular PVC tanks containing $30 \mathrm{~L}$ filtered seawater at an approximate stocking density of 50 megalopa larvae $\mathrm{L}^{-1}$ were exposed to 0 (control), 0.08 and $0.16 \mathrm{mg} \mathrm{Cu} \mathrm{L}^{-1}$ for 96 $\mathrm{h}$ with four replicates in each treatment group. Three hundred megalopa larvae were taken randomly from each tank for an exposure period of 12, 24, 48 and $96 \mathrm{~h}$, respectively, and were immediately frozen afterwards in liquid nitrogen and stored at $-80^{\circ} \mathrm{C}$ for further enzyme assays.

\section{Effect of water-borne copper on antioxidant enzyme activities and LPO}

To assess the enzyme activities, samples stored at $-80^{\circ} \mathrm{C}$ were washed by stirring in 10 volumes (v/w) of ice-cold distilled water, and homogenized in a phosphate buffer $\left(0.025 \mathrm{M} \mathrm{KH}_{2} \mathrm{PO}_{4}, 0.025 \mathrm{M} \mathrm{Na}_{2} \mathrm{PO}_{4} \cdot 12\right.$ $\mathrm{H}_{2} \mathrm{O}$, pH 7.5) with a vortex mixer at maximum speed for $30 \mathrm{~s}$. The homogenate was centrifuged at $1000 \times \mathrm{g}$ for $10 \mathrm{~min}$ at $4^{\circ} \mathrm{C}$. The supernatant was collected to determine the SOD activity. SOD activity was determined using the method of Marklund and Marklund (1974) based on the autoxidation of pyrogallol at 325 $\mathrm{nm}$ as modified by Jing and Zhao (1995). One unit of SOD was defined as the amount of enzyme that inhibits the autooxidation of pyrogallol by $50 \%$ per minute. CAT activity was determined by measuring the decrease in $\mathrm{H}_{2} \mathrm{O}_{2}$ concentration at $240 \mathrm{~nm}$ according to Aebi (1984). The reaction mixture contained 3 $\mathrm{mL}$ potassium phosphate buffer ( $\mathrm{pH} 7.0)$ and freshly prepared $10.6 \mathrm{mM} \mathrm{H}_{2} \mathrm{O}_{2}$. One unit of CAT was defined as the amount of enzyme needed to reduce 1 $\mu$ mol of $\mathrm{H}_{2} \mathrm{O}_{2}$ per minute. GST activity was evaluated according to the method of Habig and Jakobi (1981), using 1-chloro-2,4-dinitrobenzene (CDNB) as substrate. The formation of $S$-2,4-dinitro-phenyl glutathione conjugate was monitored by following the resulting absorbance at $340 \mathrm{~nm}$. One unit of activity was defined as the amount of enzyme that synthesizes $1 \mu \mathrm{mol}$ of product per minute. Total soluble protein contents were determined according to Lowry et al. (1951), using bovine serum albumin as a standard. All enzyme activities were separately expressed as a relative unit per milligram of soluble protein $(\mathrm{U} / \mathrm{mg})$.

LPO was determined according to Beuge and Aust (1972). Briefly, 100 megalopa larvae in each tank at each time point were homogenized in Tris buffer $(0.1$ M, pH 7.8) with butylhydroxytoluene (BHT) added at a final concentration of $0.01 \% \mathrm{w} / \mathrm{v}$, and centrifuged. The supernatant was mixed with TCA-TBA-HCl solution $(15 \% \mathrm{w} / \mathrm{v}$ trichloroacetic acid, $0.375 \% \mathrm{w} / \mathrm{v}$ thiobarbituric acid, $9.125 \% \mathrm{w} / \mathrm{v}$ hydrochloric acid) and placed in a boiling water bath. The formation of thiobarbituric acid-reactive components in the reaction was determined at $535 \mathrm{~nm}$, using an extinction coefficient of $1.56 \times 10^{5}$ $\mathrm{M}^{-1} \mathrm{~cm}^{-1}$ to calculate malondialdehyde equivalents (MDA) expressed as $\mu \mathrm{M}$ MDA mg protein ${ }^{-1}$.

\section{Real-time quantitative polymerase chain reaction (RT-PCR)}

Total RNA was extracted from the megalopa larvae in different treatment groups by using an RNA Extraction Kit (Axygen, Union City, USA) according to the manufacturer's protocol. RNA concentration and quality were estimated by spectrophotometry at an absorbance at $260 \mathrm{~nm}$ (Eppendorf Biophotometer plus) and agarose gel electrophoresis (Bio-Rad PowerPac ${ }^{\mathrm{TM}} \mathrm{Ba}-$ sic), respectively. Two micrograms of total RNA was reverse-transcribed using the PrimeScript ${ }^{\mathrm{TM}}$ RT-PCR Kit (TaKaRa, Japan). Real-time quantitative RT-PCR was performed in a final volume of $25 \mu$ l containing 12.5 $\mu$ l SYBR Premix Ex Taq (Perfect Real Time, TaKaRa, Japan), $2 \mu \mathrm{l}$ of cDNA template and $9.5 \mu \mathrm{l}$ or $0.5 \mu \mathrm{l}$ of primer for MT-I or actin, respectively (primer pairs MT-I-R and MT-I-F or Actin-R and Actin-F, respectively; Table 1). Amplification was performed in a C1000 ${ }^{\mathrm{TM}}$ Thermal Cycler (Bio-Rad CFX 96 ${ }^{\mathrm{TM}}$ RealTime System) under the following conditions: $95^{\circ} \mathrm{C}$ for $30 \mathrm{~s}, 40$ cycles of $95^{\circ} \mathrm{C}$ for $5 \mathrm{~s}$ and $60^{\circ} \mathrm{C}$ for 30 $\mathrm{s}$, followed by an incremental increase from $60^{\circ} \mathrm{C}$ to $95^{\circ} \mathrm{C}$ at a rate of $0.1^{\circ} \mathrm{C} / \mathrm{s}$. All samples were run in four replicates. MT-1 expression levels were analysed with the $2^{-\Delta \Delta C T}$ comparative CT method (Livak and Schmittgen 2001).

Table 1. - Sequences of the primers used in this study.

\begin{tabular}{lcc}
\hline Primer & Sequence (5'-3') & GenBank accession no. \\
\hline Actin-F (forward) & GCATCCACGAGACCACTTACA & HM053699 \\
Actin-R (reverse) & CTCCTGCTTGCTGATCCACATC & HM053699 \\
MT-I -F (forward) & GCATCTCCTTCCCAACG & GU479376 \\
MT-I -R (reverse) & GTCATCACAGCAGCCAGC & GU479376 \\
\hline
\end{tabular}




\section{Respiration trial}

Eighty megalopa larvae from each tank were used after $96 \mathrm{~h}$ of copper exposure, and randomly allotted into four $400-\mathrm{mL}$ containers with 20 megalopa larvae each; one container without megalopa larvae was used as a control. The surface was sealed with liquid wax when all megalopa larvae had settled in the tank. After $1 \mathrm{~h}$ incubation, dissolved oxygen and $\mathrm{CO}_{2}$ concentrations were determined (Chen 1998). The oxygen consumption rate $(\mathrm{R})$ and $\mathrm{CO}_{2}$ production rate $(\mathrm{P})$ were calculated from the following equation:

$$
\begin{aligned}
& \mathrm{R}\left(\mathrm{mg} \mathrm{h}^{-1} \mathrm{~g}^{-1}\right)=\left(\mathrm{O}_{0}-\mathrm{O}_{\mathrm{t}}+\mathrm{O}_{\mathrm{c}}\right) \mathrm{V} / \mathrm{W} \times \mathrm{T} \\
& \mathrm{P}\left(\mathrm{mg} \mathrm{h}^{-1} \mathrm{~g}^{-1}\right)=\left(\mathrm{C}_{\mathrm{t}}-\mathrm{C}_{0}-\mathrm{C}_{\mathrm{c}}\right) \mathrm{V} / \mathrm{W} \times \mathrm{T}
\end{aligned}
$$

where $\mathrm{O}_{0}$ is the initial oxygen concentration $\left(\mathrm{mg} \mathrm{L}^{-1}\right)$; $\mathrm{O}_{\mathrm{t}}$ is the final oxygen concentration in the megalopa larvae container $\left(\mathrm{mg} \mathrm{L}^{-1}\right) ; \mathrm{O}_{\mathrm{c}}$ is the final oxygen concentration in the control $\left(\mathrm{mg} \mathrm{L}^{-1}\right) ; \mathrm{C}_{0}$ is the initial $\mathrm{CO}_{2}$ concentration $\left(\mathrm{mg} \mathrm{L}^{-1}\right) ; \mathrm{C}_{\mathrm{t}}$ is the final $\mathrm{CO}_{2}$ concentration in the megalopa larvae container $\left(\mathrm{mg} \mathrm{L} \mathrm{L}_{-1}\right) ; \mathrm{C}_{\mathrm{c}}$ is the final $\mathrm{CO}_{2}$ concentration in the control $\left(\mathrm{mg} \mathrm{L}^{-1}\right) ; \mathrm{V}$ is the volume of the container (1); W is the wet weight of the megalopa larvae ( $\mathrm{g})$; and $\mathrm{T}$ is the duration $(\mathrm{h})$. The respiratory quotient (RQ) was calculated as RQ = $(\mathrm{R} / 32) /(\mathrm{P} / 44)$ (Li et al. 2007).

\section{Statistical analysis}

Data were expressed as mean \pm standard error $(\mathrm{SE})$. The effects of water-borne copper and exposure time on antioxidant enzyme activities and LPO values were analysed using a two-way analysis of variance (ANOVA). When significant interactions of the two factors were observed, the main effects were not further discussed, but all data were subjected to one-way ANOVA. Tukey's test was applied to detect significant differences between means $(\mathrm{P}<0.05)$. All statistical analyses were conducted using SPSS 16.0 for Windows.

\section{RESULTS}

\section{$\mathrm{LC}_{50}$ of water-borne copper in $E$. sinensis}

The estimated 24-, 48-, 72- and 96-h $\mathrm{LC}_{50}$ values and $95 \%$ confident intervals of water-borne copper for zoea 1 larvae and megalopa larvae are shown in Figure 1. The lethal effect of copper was greater for zoea 1 larvae, suggesting that they are more sensitive than megalopa larvae to different levels of water-borne copper.

\section{Effects of copper on SOD, CAT and GST activities and LPO content of $E$. sinensis larvae}

A two-way ANOVA showed that increased copper concentrations exert a significant effect on antioxidant enzyme activities and LPO content. The SOD, CAT and GST activities in the groups exposed to the highest copper concentrations $\left(0.08 \mathrm{mg} \mathrm{L}^{-1}\right.$ and $0.16 \mathrm{mg}$ $\mathrm{L}^{-1}$ ) increased significantly compared with the control

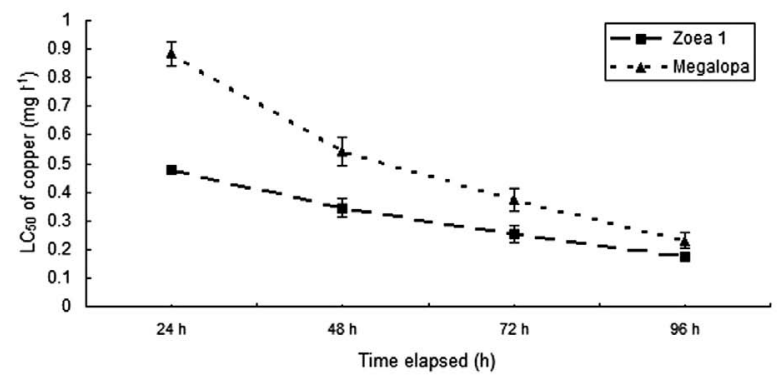

Fig. 1. $-\mathrm{LC}_{50}$ values (95\% confidence limits) of copper versus exposure time for Eriocheir sinensis zoea 1 and megalopa larvae. Values are means $\pm \mathrm{SE}(n=3)$.
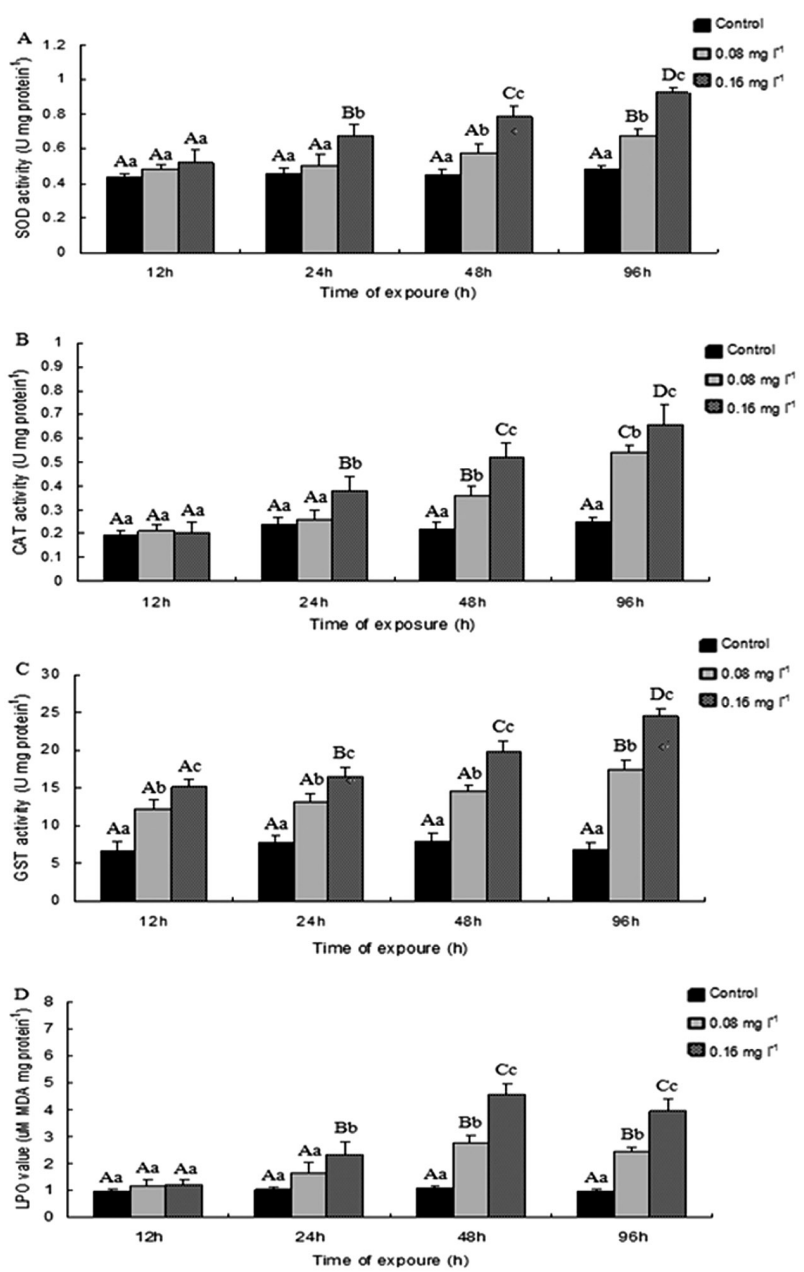

Fig. 2. - Superoxide dismutase (SOD) activity (A), catalase (B) activity, glutathione S-transferase (GST) activity (C) and lipid peroxidation (LPO) value (D) in megalopa larvae after copper treatment $\left(0,0.08 \mathrm{mg} \mathrm{L}^{-1}, 0.16 \mathrm{mg} \mathrm{L}^{-1}\right)$. Values are means $\pm \mathrm{SE}(n=4)$. Bars sharing different letters in each index are significantly different $(\mathrm{P}<0.05)$. Different lowercase letters indicate significant differences between the treatment and control groups for each exposure time. Different capital letters indicate significant differences between different exposure times for the same copper concentrations.

group after $96 \mathrm{~h}$ of exposure (Fig. 2A-C). Antioxidant enzyme activities for each treatment showed an increase in a time-dependent way. For each time point of copper exposure, the antioxidant enzyme activities in megalopa larvae were increased in comparison with the control group. After megalopa larvae had been exposed to $0.16 \mathrm{mg} \mathrm{Cu} \mathrm{L}{ }^{-1}$, the highest activities as- 


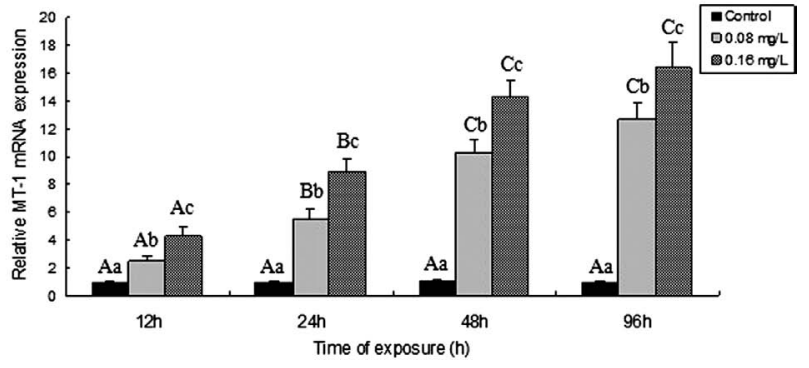

Fig. 3. - MT-1 mRNA expression in megalopa larvae after copper treatment $\left(0,0.08 \mathrm{mg} \mathrm{L}^{-1}, 0.16 \mathrm{mg} \mathrm{L}^{-1}\right)$. Expression was determined by real-time quantitative RT-PCR. Values are means \pm SE $(n=4)$. MT-1 expression was normalized to $\beta$-actin expression. Bars with different letters differed significantly $(\mathrm{P}<0.05)$. Different lowercase letters indicate significant differences between the treatment and control groups for each exposure time. Different capital letters indicate significant differences between different exposure times for the same copper concentrations.

sayed were observed at $96 \mathrm{~h}$. Moreover, the LPO of megalopa larvae exposed to 0.08 and $0.16 \mathrm{mg} \mathrm{Cu} \mathrm{L}^{-1}$ showed significant differences from the control group. In particular, after megalopa larvae were exposed to $0.16 \mathrm{mg} \mathrm{Cu} \mathrm{L}^{-1}$, the highest LPO content assayed was observed at $48 \mathrm{~h}$.

\section{Effect of copper on the MT-I mRNA expression levels in $E$. sinensis larvae}

Changes in MT-I mRNA expression levels in megalopa larvae exposed to different copper concentrations for each time point are shown in Figure 3. Increased expression levels of MT-I in megalopa larvae occurred in response to increased water-borne copper levels, and the expression levels continually increased from 12 to $48 \mathrm{~h}$. The expression level of MT-I after $96 \mathrm{~h}$ of exposure to $0.16 \mathrm{mg} \mathrm{L}^{-1}$ copper was 15 -fold higher than that in controls.

\section{Effects of copper on oxygen consumption rates and $\mathrm{CO}_{2}$ production rates in $E$. sinensis larvae}

The oxygen consumption rates, $\mathrm{CO}_{2}$ production rates and RQs of megalopa larvae at different salinities are shown in Figure 4. The oxygen consumption rates and RQs of the megalopa larvae exposed to $0.16 \mathrm{mg}$ $\mathrm{Cu} \mathrm{L}^{-1}$ for $96 \mathrm{~h}$ were significantly higher than in other treatments. No significant differences were observed in $\mathrm{CO}_{2}$ production rates between all treatments.

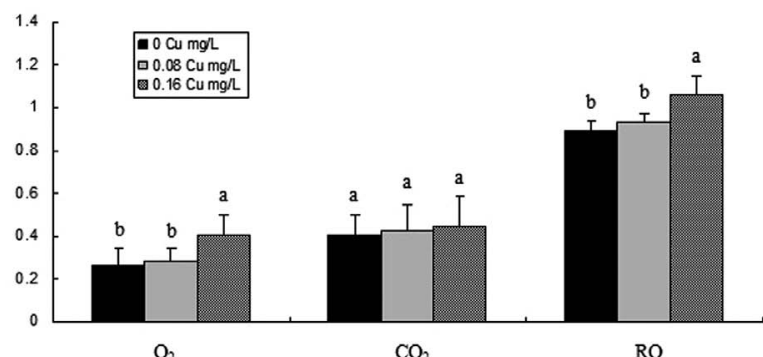

Fig. 4. - Oxygen consumption rates $\left(\mathrm{mg} \mathrm{g}^{-1} \mathrm{~h}^{-1}\right), \mathrm{CO}_{2}$ production rates $\left(\mathrm{mg} \mathrm{g}^{-1} \mathrm{~h}^{-1}\right)$ and respiratory quotient (RQ) of megalopa larvae exposed to copper. Values are means $\pm \mathrm{SE}(n=4)$. Bars sharing dif-

ferent letters in each index are significantly different $(\mathrm{P}<0.05)$.

\section{DISCUSSION}

When assayed on Lithodes santolla and larval stages, copper was shown to be an order of magnitude more toxic than other metals, resulting in the following relative scale of acute lethal toxicity: $\mathrm{Cu}>\mathrm{Pb}>\mathrm{Cd}>\mathrm{Zn}$ (Amin et al. 2003). The 96-h LC $_{50}$ values of copper for $E$. sinensis larvae were 0.16 and $0.21 \mathrm{mg} \mathrm{L}^{-1}$ at different growth stages, respectively. Copper toxicity for $E$. sinensis was of the same order of magnitude as for other crustacean larvae (Munshi et al. 1996, López Greco et al. 2001, Ferrer et al. 2003, Amin and Comoglio 2010). The results obtained in this study showed that the lethal effects of copper were greater for zoea 1 larvae, suggesting that these larvae are more sensitive than megalopa larvae to water-borne copper. The differences between the 96-h $\mathrm{LC}_{50}$ of copper for $E$. sinensis zoea 1 larvae and megalopa larvae are considered to be mainly due to their different sizes (Liang et al. 1974). The mortality of E. sinensis increased with increasing duration of exposure. This result supports previous studies in which the biochemical response of E. sinensis to water-borne copper was investigated (Yang et al. 2005, 2006a, 2006b).

ROS are caused by free metal ions, and all organisms have developed antioxidant defences with both enzymatic and non-enzymatic components. These include SOD and CAT, which can detoxify $\mathrm{O}_{2}^{-}$and $\mathrm{H}_{2} \mathrm{O}_{2}$, respectively (Fang et al. 2002), and non-enzymatic components, such as glutathione, selenium and vitamins $\mathrm{C}$ and E (El-Bahr 2013). Antioxidant enzymes are prone to oxidative modification and inactivation due to alteration by ROS and/or induction by their chemical environment (Sharonov and Churilova 1992). In this study, it is particularly interesting that we observed an increase in antioxidant enzyme activities: even at maximum copper exposure the enzymatic activity of SOD and CAT remained slightly higher than in the control. Our data agree with previous studies in aquatic animals (Hasspieler et al. 1994, Li et al. 2008), showing a positive relationship between copper exposure and copper-induced oxidative stress conditions in the tissues of organisms. Increased GST enzymatic activity at high copper concentrations could reflect a copper-induced increase in glutathione content, which plays a protective role in major detoxification processes, when the activity of the antioxidant enzyme is lowered in megalopa larvae (van der Oost et al. 2003). Our findings indicate that GST activity is sensitive to early copper exposure. Therefore, GST could be regarded as a more effective biomarker of the cellular defence system against the effects of environmental copper contamination on the physiological activities of $E$. sinensis larvae. In crustacean species, it has been shown that oxyradical production has a pollution-mediated mechanism of toxicity. LPO has been observed in individuals exposed to copper (Correia et al. 2002, Barata et al. 2005). This is consistent with our findings that megalopa larvae exposed to 0.08 and $0.16 \mathrm{mg} \mathrm{L}^{-1}$ treatments showed significantly higher levels of LPO than the control group. One reasonable explanation is that copper may act as a catalyst for the Fenton reaction, facilitating the conversion of superoxide anions and hydrogen per- 
oxide to hydroxyradicals, a species frequently proposed to initiate LPO (Stohs and Bagchi 1995).

The presence of MT has been demonstrated in many crustaceans (Olafson et al. 1979, Moksnes et al. 1995). In general, the content of MT in healthy aquatic animals is low. However, its synthesis will be increased to excess if animals are exposed to higher doses of heavy metals; thus, it plays an important role in metal detoxification, sequestration and regulation. While MT-I gene mRNA expression was low in $E$. sinensis in the control group, it was increased in $E$. sinensis exposed to copper concentrations of 0.08 and $0.16 \mathrm{mg} \mathrm{L}^{-1}$. Water-borne copper has been shown to increase MT-1 mRNA expression levels in E. sinensis juveniles (Ren et al. 2011), as our results, in which the maximum expression levels of MT-I was recorded in the groups exposed to $0.16 \mathrm{mg} \mathrm{L}^{-1}$ copper for 48 or $96 \mathrm{~h}$. Our results suggest that MT-I mRNA expression levels could be used as a bioindicator for monitoring aquatic copper pollution for $E$. sinensis larvae.

In the present study, the oxygen consumption and RQs of the megalopa larvae exposed to water-borne copper $\left(0.16 \mathrm{mg} \mathrm{L}^{-1}\right.$ for $\left.96 \mathrm{~h}\right)$ were significantly higher than in other treatments. Oxygen consumption and other indices related to respiration and metabolism have been used to assess physiological responses under various stressful environments in decapod crustaceans (Li et al. 2007, Dissanayake et al. 2008, Amin and Comoglio 2010). High oxygen consumption and RQs after copper exposure have been attributed to ultrastructural damage to the gill epithelium (Yang et al. 2007), and their increases reflect an extra metabolic demand in copper-exposed animals. In the present study, the approximate RQ of 0.9 indicates reliance on a mixture of carbohydrates, lipids and proteins for energy. This value is higher than the RQ of 0.7 found in another freshwater crab, Potamonautes warreni, after prolonged exposure to copper (Vosloo et al. 2002). The highest copper concentration employed in the physiological and biochemical analysis $\left(0.16 \mathrm{mg} \mathrm{L}^{-1}\right)$, which represents about $70 \%$ of the estimated $96-\mathrm{h} \mathrm{LC}_{50}$, had visible effects on the analysed parameters. Furthermore, a report on the Chinese fishery eco-environment emphasized that copper is the most commonly encountered heavy-metal pollutant. An average concentration of $0.07 \mathrm{mg} \mathrm{L}^{-1}$ water-borne copper has been documented in some fishing areas of the Yangtze River, Hangzhou Bay and the coast of Zhoushan on the East China Sea (Ministry of Agriculture and State Environmental Protection Administration 2004), which would be comparable to exposure levels analysed in our study $\left(0.08 \mathrm{mg} \mathrm{L}^{-1}\right)$. However, further studies are needed to investigate the impact of such a high heavy-metal presence in the coastal zone of China on other aspects of crab larvae, such as moulting, bioaccumulation and immune responses.

In conclusion, acute dissolved copper toxicity (96-h $\mathrm{LC}_{50}$ and its corresponding $95 \%$ confidence interval) was determined for $E$. sinensis zoea 1 and megalopa larvae. This study showed that megalopa larvae are able to survive under high concentrations of copper through various functional adaptations, such as high- energy expenditure towards respiration, induced MT-I synthesis and stimulated antioxidant systems. Therefore, MT-I mRNA expression levels and GST activity could be used as an effective method to monitor waterborne copper stress in E. sinensis larvae in aquaculture.

\section{ACKNOWLEDGEMENTS}

The project was supported by the Twelfth National Five-Year Plan for Science \& Technology Support (2012BAD26B04; 2012BAD25B07) and the Science \& Technology Supporting Programme of Jiangsu Province (BE2012334).

\section{REFERENCES}

Aebi H. 1984. Catalase in vitro. In: Packer, L. (ed.), Methods in Enzymology, vol. 105. Academic Press Inc., San Diego, pp. 121-126.

Agrahari KC. 2009. Heavy metals in aquatic ecosystem: some environmental implications. Everyman's Science, Vol. XLIV No. 2. pp. 88-93.

Amin O.A., Comoglio L.I. 2010. Effects of copper on the physiological responses of the commercial crab Lithodes santolla (Decapoda: Anomura) larvae. Sci. Mar. 74: 25-31. http://dx.doi.org/10.3989/scimar.2010.74n2215

Amin O., Comoglio L., Rodríguez E. 2003. Toxicity of Cadmium, Lead, and Zinc to larval stages of Lithodes santolla (Decapoda, Anomura). Bull. Environ. Contam. Toxicol. 71: 527-534. http://dx.doi.org/10.1007/s00128-003-8611-9

Bambang Y., Thuet P., Charmantier-Daures M., Trilles J.P., Charmantier G. 1995. Effect of copper on survival and osmoregulation of various developmental stages of the shrimp Penaeus japonicus Bate (Crustacea, Decapoda). Aquat. Toxicol. 33: 125-139. http://dx.doi.org/10.1016/0166-445X(95)00011-R

Barata C., Varo I., Navarro J.C., Arun S., Porte C. 2005. Antioxidant enzyme activities and lipid peroxidation in the freshwater cladoceran Daphnia magna exposed to redox cycling compounds. Comp. Biochem. Physiol. C 140: 175-186.

Beuge J.A., Aust S.D. 1972. Microsomal Lipoperoxidation. Methods. Enzymol. 52: 302-307.

Brouwer M., Schlenk D., Ringwood A.H., Brouwer-Hoexum T.M. 1992. Metal-specific induction of metallothionein isoforms in the blue crab, Callinectes sapidus. Arch. Biochem. Biophys. 294: 461-468. http://dx.doi.org/10.1016/0003-9861(92)90712-6

Brouwer M., Enghild J., Hoexum-Brouwer T.M., Thogersen I., Truncali A. 1995. Primary structure and tissue-specific expression of blue crab (Callinectes sapidus) metallothionein isoforms. Biochem. J. 311: 617-622.

Brouwer M., Syring R., Brouwer T.H. 2002. Role of a copperspecific metallothionein of the blue crab, Callinectes sapidus, in copper metabolism associated with degradation and synthesis of hemocyanin. J. Inorg. Biochem. 88: 228-239. http://dx.doi.org/10.1016/S0162-0134(01)00381-6

Chen J.R. 1998. Experimental Direction Book for Aquatic Chemistry. China agricultural Press, Beijing, pp. 120-126.

Chourpagar A.R., Kulkarni G.K. 2011. Heavy metal toxicity to a freshwater crab, Barytelphusa cunicularis (Westwood) from Aurangabad region. Recent. Res. Sci. Technol. 3: 1-5.

Correia A.D., Livingstone D.R., Costa M.H. 2002. Effects of waterborn copper on metallothionein and lipid peroxidation in the marine amphipod Gammarus lacusta. Mar. Environ. Res. 54: 357-360. http://dx.doi.org/10.1016/S0141-1136(02)00114-9

Coyle P., Philcox J.C., Carey L.C., Rofe A.M. 2002. Metallothionein: the multipurpose protein. Cell. Mol. Life. Sci. 59: 627-647. http://dx.doi.org/10.1007/s00018-002-8454-2

D’Adamo R., Di Stasio M., Fabbrocini A., Petitto F., Roselli L., Volpe M.G. 2008. Migratory crustaceans as biomonitors of metal pollution in their nursery areas. The Lesina lagoon (SE Italy) as a case study. Environ. Monit. Assess. 143: 15-24. http://dx.doi.org/10.1007/s10661-007-9944-3

De Boeck G.D., Ngo T.T.H., Campenhout K.V., Blust R. 2003. Differential metallothionein induction patterns in three freshwater fish during sublethal copper exposure. Aquat. Toxicol. 65: 413424. http://dx.doi.org/10.1016/S0166-445X(03)00178-4 
Dissanayake A., Galloway T.S., Jones M.B. 2008. Physiological responses of juvenile and adult shore crabs Carcinus maenas (Crustacea: Decapoda) to pyrene exposure. Mar. Environ. Res. 66:445-450. http://dx.doi.org/10.1016/j.marenvres.2008.07.006

El-Bahr S.M. 2013. Biochemistry of free radicals and oxidative stress. Sci. Int. 1: 111-117. http://dx.doi.org/10.5567/sciintl.2013.111.117

Fang Y., Yang S., Wu G. 2002. Free radicals, antioxidants, and nutrition. Nutrition. 18: 872-879. http://dx.doi.org/10.1016/S0899-9007(02)00916-4

Ferrer L.D., Andrade J.S., Contardi E.T., Asteasuaian R.O., Marcovecchio J.E. 2003. Copper and zinc concentrations in Bahía Blanca Estuary (Argentina), and their acute lethal effects on larvae of the crab Chasmagnathus granulata. Chem. Speciat. Bioavailab. 15: 7-14 http://dx.doi.org/10.3184/095422903782775271

Finney D.J. 1971. Probit analysis. 3rd edition. Cambridge University Press, Cambridge.

Habig W., Jakobi W.B. 1981. Glutathione S-transferase (rat and human). Methods of Biochemical alterations in rats subjected to dermal application of dodine. Ind. Comput. Physiol. 9: 27-31.

Haq F., Mahoney M., Koropatnick J. 2003. Signaling events for metallothionein induction. Mutat. Res. 533: 211-226. http://dx.doi.org/10.1016/j.mrfmmm.2003.07.014

Hasspieler B.M., Behar J.V., Di Giulio R.T. 1994. Glutathionedependent defense in channel catfish (Ictalurus punctatus) and brown bullhead (Ameriurus nebulosus). Ecotoxicol. Environ. Safety. 28: 82-90. http://dx.doi.org/10.1006/eesa.1994.1036

Hou Y.X., Wang Y, Li H.Y., Li X.X., Hu X.J. 2011. Accumulation and distribution of heavy metals in Phragmites australis in the wetland of Liaohe river estuary. Adv. Mater. Res. 994: 356-360.

Hotard S, Zou E. 2008. Activity of glutathione S-transferase in the hepatopancreas is not influenced by the molting cycle in the fiddler crab, Uca pugilator. Bull. Environ. Contam. Toxicol. 81: 242-244. http://dx.doi.org/10.1007/s00128-008-9487-5

Jing T.Y., Zhao X.Y. 1995. The improved pyrogallol method by using terminating agent for superoxide dismutase measurement. Prog. Inorg. Biochem. Biophys. 1: 13-15.

Leung K.M.Y., Furness R.W. 1999. Induction of metallothionein in dogwhelk Nucella lapillus during and after exposure to cadmium. Ecotoxicol. Environ. Safe. 43:156-164. http://dx.doi.org/10.1006/eesa.1999.1769

Li Q.S., Li Y.T. 2003. Practical manual for water environmental monitoring. China Waterpower Press, Beijing, China, 433.

Li N., Zhao Y.L., Yan J. 2008. Effects of water-borne copper on digestive and metabolic enzymes of the giant freshwater prawn Macrobrachium rosenbergii. Arch. Environ. Contam. Toxicol. 55: 86-93. http://dx.doi.org/10.1007/s00244-007-9099-9

Li E.H., Chen L.Q., Zeng C., Chen X.M., Yu N., Lai Q.M., Qin J.G. 2007. Growth, body composition, respiration and ambient ammonia nitrogen tolerance of the juvenile white shrimp, Litopenaeus vannamei, at different salinities. Aquaculture. 265: 385-390. http://dx.doi.org/10.1016/j.aquaculture.2007.02.018

Liang X.Q., Yan S.L., Zheng D.C., Guo D.D. 1974. Larval development of Eriocheir sinensis H. Milne-Edwards. Acta. Zoologica. Sinica. 20: 61-75. (in Chinese with English abstract).

Lin S., Hsieh I.J., Huang K.M., Wang C.H. 2002. Influence of the Yangtze River and grain size on the spatial variations of heavy metals and organic carbon in the East China Sea continental shelf sediments. Chem. Geol. 182: 377-394. http://dx.doi.org/10.1016/S0009-2541(01)00331-X

Livak K.J., Schmittgen T.D. 2001. Analysis of relative gene expression data using real-time quantitative PCR and the 2(-Delta Delta C(T)) method. Methods 25: 402-408. http://dx.doi.org/10.1006/meth.2001.1262

López Greco L.S., Sánchez M.V., Nicoloso G.L., Medesani D.A., Rodríguez E.M. 2001. Toxicity of cadmium and copper on larval and juvenile stages of the estuarine crab Chasmagnathus granulata (Brachyura, Grapsidae). Arch. Environ. Contam. Toxicol. 41: 333-338. http://dx.doi.org/10.1007/s002440010256

Lowry O.H., Rosenbrough N.J., Farr A.L., Randall R.J. 1951. Protein measurement with a Folin reagent. J. Biol. Chem. 193: 265-275.

Marklund S., Marklund G. 1974. Involvement of superoxide anion radical in the autoxidation of pyrogallol and a convenient assay for superoxide dismutase. Eur. J. Biochem. 47: 469-474 http://dx.doi.org/10.1111/j.1432-1033.1974.tb03714.x

Moksnes P.O., Lindahl U., Haux C. 1995. Metallothionein as a bioindicator of heavy-metal exposure in the tropical shrimp Penaeus vanname, a study of dose-dependent indication. Mar. Environ. 39: 143-146. http://dx doi.org/10.1016/0141-1136(94)00057-V

Martins Cde M., Barcarolli I.F., de Menezes E.J., Giacomin M.M., Wood C.M., Bianchini A. 2011. Acute toxicity, accumulation and tissue distribution of copper in the blue crab Callinectes sapidus acclimated to different salinities: In vivo and in vitro studies. Aquat. Toxicol. 17: 88-99. http://dx.doi.org/10.1016/j.aquatox.2010.09.005

Ministry of Agriculture, State Environmental Protection Administration. 2004. Report on state of the fishery eco-environment in China. Ministry of Agriculture, State Environmental Protection Administration, Beijing, China, pp. 3-7.

Munshi A.B., Quan S.Y., Li, S.J. 1996. Acute toxicity of cop-per, cadmium and copper-cadmium mixture to the larvae of the shrimp Penaeus monodon. Pak. J. Sci. Res. 39: 68-71.

Olafson R.W., Kearns A., Sim R.G. 1979. Heavy metal induction of metallothionein synthesis in the hepatopancreas of the crab Scylla serrata. Comp. Biochem. Physiol. B 62: 417-424. http://dx.doi.org/10.1016/0305-0491(79)90112-3

Rainbow P.S., 1992. The significance of accumulated heavy metal concentrations in marine organisms. In: Proceedings of bioaccumulation workshop, Water Board and Australian Marine Sciences Association Inc., Sydney.

Ren F., Jiang H., Sun J., He L., Li W.W., Wang Y, Wang Q. 2011. Cloning, characterization, expression, and copper sensitivity of the metallothionein-1 gene in the Chinese mitten crab, Eriocheir sinensis. Mol. Biol. Rep. 38: 2383-2393. http://dx.doi.org/10.1007/s11033-010-0372-z

Sharonov B.P., Churilova I.V. 1992. Inactivation and oxidative modification of $\mathrm{Cu}, \mathrm{Zn}$ superoxide dismutase by stimulated neutrophils: the appearance of new catalytically active structures. Biochem. Biophys. Res. Commun. 189: 1129-1135. http://dx.doi.org/10.1016/0006-291X(92)92321-N

Stohs S.J., Bagchi D. 1995. Oxidative mechanisms in the toxicity of metal ions. Free. Radic. Biol. Med. 18: 321-336. http//dx doi.oro/10.1016/0891-5849(94)00159-H

Sunda W.G., Hanson A.K. 1987. Measurement of free cupric ion concentration in seawater by a ligand competition technique involving copper sorption onto C18 SEP-PAK cartridge. Limnol. Oceanog. 32: 537-551. http://dx.doi.org/10.4319/1o.1987.32.3.0537

Syring R.A., Brouwer T.H., Brouwer M. 2000. Cloning and sequencing of cDNAs encoding for a novel copper-specific metallothionein and two cadmium-inducible metallothioneins from the blue crab Callinectes sapidus. Comp. Biochem. Physiol. C 125: 325-332.

van der Oost R., Beyer J., Vermeulen N.P.E. 2003. Fish bioaccumulation and biomarkers in environmental risk assessment: a review. Environ. Toxicol. Pharmacol. 13: 57-149. http://dx.doi.org/10.1016/S1382-6689(02)00126-6

Vosloo A., Van Aardt W.J., Mienie L.J. 2002. Sublethal effects of copper on the freshwater crab Potamonautes warreni. Comp. Biochem. Physiol. A 133: 695-702. http://dx.doi.org/10.1016/S1095-6433(02)00214-3

Yang Z.B., Zhao Y.L., Zhou Z.L., Zhou X., Yang J. 2005. Effects of copper in water on distribution of copper and digestive enzymes activities in Eriocheir sinensis. J. Fish. China. 29: 496-501. (in Chinese with English abstract).

Yang Z.B., Zhao Y.L., Zhou Z.L., Yang J. 2006a. Effects of $\mathrm{CuSO}_{4}$ on molting, growth, and survival of Eriocheir sinensis. Acta. Hydrobiol. Sin. 30: 563-569. (in Chinese with English abstract).

Yang Z.B., Zhao Y.L., Zhou Z.L., Li N., Yang J. 2006b. Effects of water-borne copper on activities of metabolism enzymes in the crab Eriocheir sinensis. Oceanol. Limnol. Sin. 37: 118-124. (in Chinese with English abstract).

Yang Z.B., Zhao Y.L., Li N., Yang J. 2007. Effect of water-borne copper on the microstructures of gill and hepatopancreas in Eriocheir sinensis and its induction of metallothionein synthesis. Arch. Environ. Contam. Toxicol. 52: 222-228. http://dx.doi.org/10.1007/s00244-006-0133-0

Yeh S.T., Liu C.H., Chen J.C. 2004. Effect of copper sulphate on the immune response and susceptibility to Vibrio alginolyticus in the white shrimp Litopenaeus vannamei. Fish. Shellfish. Immunol. 17: 437-446. http://dx.doi.org/10.1016/j.fsi.2004.04.016

Zapata V., López Greco L., Rodríguez E. 2001. Effect of copper on hatching and development of larvae of the estuarine crab Chasmagnathus granulata (Decapoda, Brachyura). Environ. Toxicol. Chem. 20: 1579-1583. 